\begin{tabular}{rr} 
çağdaş & Yaratıcı Drama Dergisi 2015, 10(1), 1-14 \\
drama & www.yader.org \\
\hline
\end{tabular}

\title{
Coğrafya Öğretmen Adaylarının Yaratıcı Drama Yöntemine İlişkin Görüşleri
}

\author{
Mehmet Akif Bütün ${ }^{1}$
}

Ahmet Tüzüner ${ }^{2}$

Neşe Duman ${ }^{3}$

\begin{tabular}{|c|c|}
\hline Makale Bilgisi & Öz \\
\hline DOI: 10.21612 yader.2015.001 & \multirow[b]{3}{*}{ 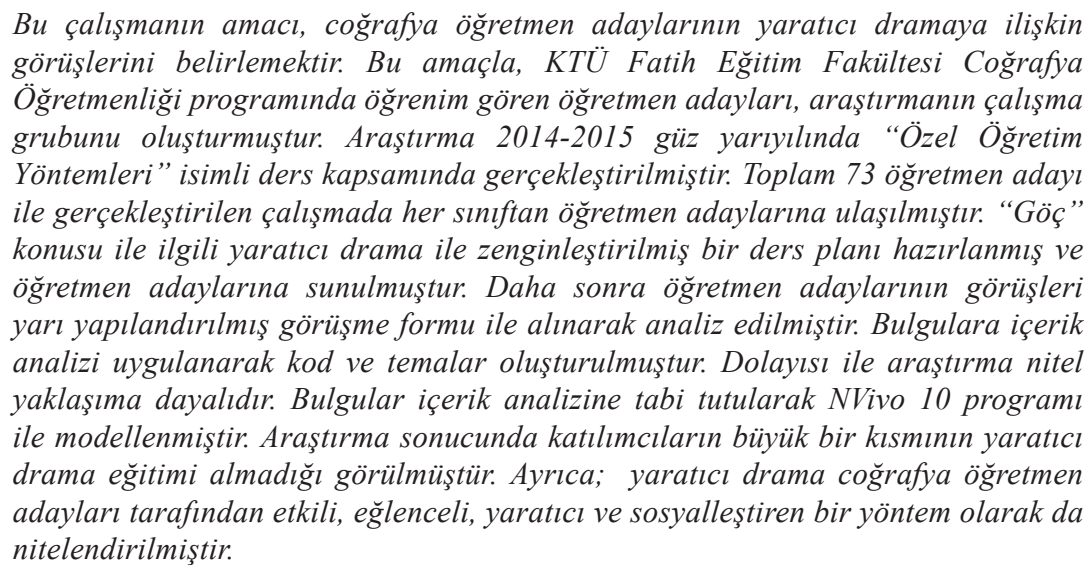 } \\
\hline Anahtar Sözcükler & \\
\hline $\begin{array}{l}\text { Coğrafya öğretimi } \\
\text { Yaratıcı drama } \\
\text { Öğretmen eğitimi }\end{array}$ & \\
\hline
\end{tabular}

\section{The Opinions of Geography Teachers About Creative Drama on Geography Teaching}

\begin{tabular}{l} 
Article Info \\
\hline DOI: $10.21612 /$ yader.2015.001 \\
\hline Keywords \\
Geography teaching \\
Creative drama \\
Teacher education
\end{tabular}

\begin{abstract}
The aim of this study was to determine views of geography teacher candidates on creative drama. To this end, 73 teacher candidates of KTU Fatih Faculty of Education, Geography Education Program took part as the reserach group. The research was held during the 'Teachig Methods' course that commenced 2014-2015 fall semester. A lesson plan was enriched with creative drama and presented to the research group. A qualitative approach was conducted to examine the opinions of the teachers in this study. After the lesson conducted with creative drama, the views of the teacher candidates were asked using semi-structured interview form. The results are modeled with NVivo 10 program which were subjected to content analysis. The opinions of teacher candidates were collected with semi-structured form which was followed by the content analysis. The result of the study is that the majority of the participants had not formarly taken creative drama education. Creative drama is also described by geography teacher candiates as effective, fun, creative, socializing.
\end{abstract}

\footnotetext{
Karadeniz Teknik Üniversitesi, Fatih Eğitim Fakültesi, Coğrafya Öğretmenliği, E-posta: mehmetakif-60@hotmail.com Karadeniz Teknik Üniversitesi, Fatih Eğitim Fakültesi, Coğrafya Öğretmenliği, E-posta: ahmet.tuzuner@hotmail.com Yrd. Doç. Dr. Çankırı Karatekin Üniversitesi, Edebiyat Fakültesi, Coğrafya Bölümü, E-posta: nesekduman@gmail.com
} 


\section{Giriş}

Drama sözcüğü, tam Türkçe karşılığı bulunmamakla birlikte, Yunanca “dran” sözcüğünden türetilmiştir. Dran; yapmak, etmek, eylemek anlamını taşımaktadır. Drama ise eylem anlamını taşıyan, yine Yunanca "dromenon"un seyirlik olarak benzetmecisi biçiminde kullanımıdır. Türkçe'de kullanılan "dram" kavramı ise, Fransızcadaki sonu "e" ile biten "drame" sözcügünden gelmektedir; o dilde "burjuva tiyatrosu" anlamına geldiği halde, Türkçede özellikle halk dilinde "acıklı oyun" anlamında kullanılagelmiştir. Türkiye'de alanın önemli otoritelerinden olan İnci San ise dramayı; "İnsanın insanla giriştiği her tür dolaysız, doğrudan ilişki, etki tepki alışverişi ve en az düzeyde bir etkileşimin olduğu bir dramatik an ya da dramatik durum" olarak tanımlar(1990, s. 573). Freeman, Sullivan ve Fulton (2003) ise dramayı, katılımcılara fayda sağlaması için oluşturulan dramatik deneyimler olarak ifade etmektedir. O’Neill ve Lambert (1995), dramanın sosyal bir süreç olduğunu, sosyal iletişime ve grupla çalışmaya olanak tanıyarak sosyal becerilerin gelişmesinde rol oynadığını belirtmektedir (Akt: Çelikkaya, 2014, s. 449). Adıgüzel'e göre (2013, s. 45) yaratıcı drama; bir grubu oluşturan üyelerin, yaşam deneyimlerinden yola çıarak, bir amacın, düşüncenin, doğaçlama, rol oynama (rol alma) vb. tekniklerden yararlanarak canlandırmasıdır. Bu canlandırma süreçleri deneyimli bir lider/eğitmen eşliğinde yürütülürken kendiliğindenliğe, şimdi ve burada ilkesine, -mış gibi yapmaya dayalıdır ve yaratıcı drama, oyunun genel özelliklerinde doğrudan yararlanır.

18. yüzyılda gelişen romantizmin etkisi yaratıcı dramanın gelişiminde olduğu kadar eğitimi de etkileyen bir akımdır. Eğitime ilerlemeci anlayışın hakim olması sonucunda ortaya çıkmıştır. $\mathrm{Bu}$ hareketin temelinde, öğrenenin merkezde olduğu ve düşüncelerinin önemli olduğu anlayış1 yatmaktadır. Eğitimde drama, İngiltere üzerinden Avrupa'ya ve Kuzey Avrupa ülkelerine, özellikle Dorothy Heathcote'un uluslararası atölye çalışmaları ile İngilizce konuşan diğer ülkelere yayılmış, okulların eğitim programlarında yer almıştır (Adıgüzel, 2013, s. 147-148). Ülkemizde ise drama ile ilgili ilk çalışmaların İsmail Hakkı Baltacığlu ve Muhsin Ertuğrul'a ait olduğu söylenebilir. 1950 yılında Selahattin Çoruh tarafından "Okullarda Dramatizasyon” isimli kitap yazılmıştır. 1960'da Emin Özdemir’in “Uygulamalı Dramatizasyon” isimli bir kitapçı̆̆ı yayınlanmıştır. 1980 başlarında tiyatro sanatçısı Tamer Levent, genç ve amatör tiyatrocularla doğaçlama çalışmalarına başlamıştır. 1982'de Ankara Üniversitesi Eğitim Bilimleri Fakültesinde 70 öğrenci ile başlanılan çalışmalar, eğitimde yaratıcı dramanın başlangıcı kabul edilmektedir. Daha sonra Eylül 1998'de MEB Talim Terbiye kurulunca yayımlanan tebliğler dergisinde, 1997-1998 öğretim yılından başlayarak ilköğretim 4., 5., 6., 7. ve 8. sınıflara seçmeli ders olarak girmiştir (San, 2010, s. 18-23). 1998 yılında Eğitim Fakültelerinin Okulöncesi Öğretmenliği, Sınıf Öğretmenliği, Türkçe Öğretmenliği ve Yabanc1 Dil Öğretmenliği bölümlerinde drama, mecburî ders olarak okutulmuştur. 2006 yılında Eğitim Fakültelerindeki program yeniden değerlendirilmiş ve Beden Eğitimi Öğretmenliği, İlköğretim Sosyal Bilgiler Öğretmenliği, İşitme Engelliler ve Üstün Zekâlılar öğretmenliği bölümlerinde de mecburî ders olarak yer almıştır (Yeğen, 2008, s. 17-23).

Görüldüğü üzere pek çok branş öğretmenliğinin programına mecburi veya seçmeli olarak yerleştirilen bu dersin kişisel gelişim üzerine bir çok faydası saptanmıştır. Bunlar şu şekildedir: Serbest düşünme becerisi kazandırır. Zihinsel uygulamalarda esneklik katarak, fikir akıcılığı sağlar. Yaratıcılık ve estetik algısının gelişimlerine katkıda bulunur. Etkili zihinsel süreçlere sahip olmayı sağlayarak, durumları belirleme kapasitesini ve dikkati artırır, yoğunlaşmayı sağlar. Deneyimlere 
açık olmayı olduğu için öğretmenin sosyal uyumsuzlukları ve öğrenme problemlerini teşhis etmesine yardımcı olur. Kendini ve başkalarını anlama becerisini geliştirmeye yardımcıdır. İletişim becerilerine olumlu bir katkı sağlar. Kendine güven duyma, destekleme, karar verme becerisi kazandırır. Beden dilini kullanmayı sağlar. Duygularının farkına varma ve onları ifade etmeyi sağlar. Yaratıcı drama, bireyin bilinçlenmesi, toplumsal bir varlık olabilmesi konusunda geliştirici özelliğe sahiptir. Soyut konuları somut hale getirerek öğrenmenin kalıcılığına katkıda bulunur. Konuyu ilgi çekici hale getirir. Dil gelişiminde; konuşurken kendine güven duymanın gelişmesi, kelime hazinesinin artması, fikirlerin ifade edilmesi, insanlarla ilişki kurma becerisinin kazanılması, farklı durumlarda farklı dilin kullanılması, tanımlama, tartışma ve değerlendirme becerilerinin gelişmesini sağlar (MEB, 2006, s. 25-26).

Milli Eğitim Bakanlığı, 2005-2006 eğitim-öğretim yılından itibaren ortaöğretim kurumlarında yapılandırmacı yaklaşıma göre hazırlanan yeni öğretim programının uygulamasına geçmiştir. $\mathrm{Bu}$ vesile ile geleneksel öğretim yöntemleri yerini öğrencilerin kendilerini rahatça ifade edebilecekleri yöntemlere bırakmıştır. Bu açıdan bakıldığında Coğrafya dersi öğretim programı da bu değişimden etkilenmiştir. Coğrafya eğitiminin 'Bilgi kadar, beceri ve değer eğitiminin de önem arz ettiği bir anlayış üzerine temellenmesi gerektiği' fikri hakim olmaya başlamıştır. Bu gelişmeler doğrultusunda amaç ve beceriler güncellenmeye çalışılmıştır. Coğrafya biliminin; “Temel kavram, kuram ve metodolojisini kullanarak araştırmalar yapma, insan-doğa ilişkisi çerçevesinde coğrafi sorgulama becerileri kazanma, evrene ait temel unsurları yaşamla ilişkilendirme, doğal ve beşerî sistemlerin işleyiş ve değişimini kavrama, yakın çevresinden başlayarak ülkesine ve dünyaya ait mekânsal değerlere sahip çıkma bilinci geliştirme, ekosistemin işleyişine yönelik sorumluluk bilinci geliştirme, coğrafi değerlerin "Vatan bilincinin" kazanılmasındaki önemini özümseme" gibi genel amaçları bulunmaktadır (MEB, 2011, s. 8). Ortaöğretim Coğrafya dersi öğretim programında yer alan bu genel amaçlar, dramanın amaçları ile (empati kurma, sorumluluk duygusu geliştirme, öğrenilenlerin kalıcı olmasını sağlama, sosyal farkındalığın artmasına ve problem çözme yeteneğinin gelişmesine yardımcı olma gibi) örtüşmektedir. Diğer yandan yaratıcı dramanın; yaratıcılığı ve hayal gücünü geliştirme, kendini tanıma ve gerçekleştirme, iletişim becerisini geliştirme, demokratik tutum ve davranış geliştirme, eleştirel ve bağımsız düşünebilme, iş birliği yapabilme-birlikte çalışma, sosyal duyarl11ı yaratma becerilerini geliştirme gibi özellikleri de (Adıgüzel, 2013, s. 66-71) Coğrafya dersi öğretim programında yer alan becerilerin (gözlem, coğrafi sorgulama, zamanı algılama, değişim ve sürekliliği algılama, kanıt kullanma becerisi gb.) kazandırılmasında oldukça gereksinim duyulacak niteliktedir.

Coğrafya eğitim ve öğretiminde drama ya da yaratıcı drama konusu ile ilgili yapılan literatür taramasında oldukça sınırlı sayıda çalışmaya ulaşılmıştır. Bu sebeple özellikle Sosyal Bilgiler öğretimi kapsamında coğrafya konuları üzerine yapılan çalışmalar taranarak özetlenmeye çalışılmıştır. Bu bağlamda araştırmanın literatürdeki bu boşluğu dolduracağ düşünülmektedir. Aşağıda ilgili literatür özetlenmiştir;

“İlköğretim 5. sınıf Sosyal Bilgiler dersi coğrafya konularının öğretimde drama yönteminin kullanılması (Kazan ilçesi örneği)" adlı yüksek lisans tezinde (Özcan, 2004), drama yönteminin öğrencilerin öğrenme düzeylerini arttıracă̆1 sonucuna varılmıştır. Koç (1999), "Yaratıcı Dramanın Öğrenmeye Etkisi-Sosyal Bilgiler Öğretimde Bir Yöntem Olarak-" başlıklı Yüksek lisans tezi 
çalışmasında, yaratıcı drama yönteminin öğrenmeye etkisini araştırmak üzere ilköğretim 4. Sınıf Sosyal Bilgiler dersinin «Türklerin Anadolu〉ya Yerleşmesi» ünitesinin öğretiminde yaratıcı drama yöntemini kullanarak yöntemin öğrenci başarısı üzerine etkilerini araştırmıştır. Araştırmada sonuç olarak yaratıcı dramanın yöntem olarak etkili olduğu, uygun konuların seçilerek öğretimde kullanılmasının yararlı olacağı sonucuna varılmıştır. Debre (2008), “İlköğretim Sosyal Bilgiler Dersi Coğrafya Konularının Öğretiminde Ders Anlatım Stratejisi Olarak Dramatizasyonun Kullanılmasının Öğrencinin Başarı Düzeyine Etkisi” adı ile yapılan yüksek lisans tezinde, dramatizasyon yöntemiyle işlenen dersin geleneksel yöntemlerle işlenen derslere göre başarıyı arttırdığını belirtmiştir. Akkaya (2012)'nın, “Sosyal Bilgilerde Göç Konusunun Drama Yöntemiyle Öğretiminin Akademik Başarıya Etkisi” adlı yüksek lisans tezinde amaç, İlköğretim 2. kademe Sosyal Bilgiler dersi göç konusunun drama yöntemi ile öğretiminin yapıldığı modelin öğrencilerin akademik başarısı üzerine etkisinin ortaya konulmasıdır. Araştırma, yöntemin öğrenci başarısı üzerinde güçlü etkiye sahip olduğunu göstermiştir. Deney grubu öğrencileri süreci; eğlenceli, kalıcı, anlaşılır, faydalı, empati becerilerini geliştirir nitelikte betimlemişlerdir. Rüzgâr (2014)'ın çalışması, 6.sınıf Sosyal Bilgiler dersi “İpek Yolunda Türkler” ünitesinde geçen göç kavramının drama yöntemiyle işlenmesinin öğrenci başarısına etkisini ortaya çıkarmak amacıyla yapılmıştır. Araştırmada drama yönteminin Sosyal Bilgiler dersinde kullanılmasının, geleneksel yöntemlere göre öğrenci başarısı üzerinde nispeten olumlu bir etkisinin olduğu sonucuna ulaşılmıştır. Atar'ın 2003 yılında yaptığı yüksek lisans tezi çalışması, eğitici dramanın, sosyal bilgiler dersi coğrafya konularının öğretiminde hatırda tutma ve başarı düzeyleri üzerindeki etkisini ortaya koymak amacıyla yapılmıştır. Araştırma deneysel bir çalışma olup ön test, son test, kontrol test gruplu modele uygun olarak hazırlanmıştır. Sonuç olarak, drama yöntemi kullanılarak ders işlenen grupta öğrenmenin ve öğrenilenlerin akılda kalıcılığının daha fazla olduğu görülmüştür. "İlköğretim 6. Sınıf Sosyal Bilgiler Dersi “Coğrafya ve Dünyamız” Ünitesinde Yaratıcı Drama Yöntemi Kullanımının Öğrenci Başarısı ve Tutumlarına Etkisi” isimli yüksek lisans tezinin sonucunda, yaratıcı dramanın uygulandığı deney grubu ile geleneksel yöntemin uygulandığı kontrol grubu arasında bilişsel alanın bilgi düzeyine yönelik anlamlı bir farklılık bulunmuştur. $\mathrm{Bu}$ sonuç da yaratıcı drama ile öğretimin daha etkili olduğunu göstermiştir (Zayimoğlu, 2006). "Öğretmen adaylarının drama öz yeterliliği ve coğrafya, tarih ve vatandaşlık bilgileri konularında drama kullanımı” adlı çalışmada amaç, öğretmen adaylarının drama öz yeterliklerini ve coğrafya, tarih ve vatandaşlık bilgileri konularında drama kullanımlarını değerlendirmektir. Sonuçlar öğretmen adaylarının coğrafya, tarih ve vatandaşlık konularında drama destekli öğretimi benimsediklerini ortaya koymaktadır (Turan, Kuğuoğlu ve Albayrak, 2012). "Ortaöğretim 9. Sinıf Coğrafya Dersi Konularının (Yerkürenin günlük hareketi, iklim bilgisi, toprak coğrafyası, jeolojik zamanlar) Öğretiminde Drama Yöntemi ile Klasik Yöntemlerin Karşılaştırılması” adı ile yapılan yüksek lisans tezi çalışmasında, drama yöntemi ile öğrenilen bilgilerin klasik yöntemlerle öğrenilen bilgilerden daha kalıcı olduğu ortaya çıkmaktadır (Esen, 2008). Köseoğlu ve Ünlü (2006) 'nün yaptıkları çalışmada, deney grubuna coğrafya öğretiminde problem çözme yöntemi olarak dramatizasyon kullanılarak Dramatizasyonun akademik başarı ve hatırlama düzeyine etkisi araştırılmıştır. Kontrol grubundaki öğrencilerle yapılan çalışmada ise problem çözme süreci içerisinde yalnız problemin okunması ve doğrudan çözümlenmesi gibi klasik metotlar kullanılmıştır. Araştırmanın sonucunda, Coğrafya dersinde dramatizasyon yoluyla problem çözmenin, başarı ve hatırlama düzeyini anlamlı derecede arttırdığı görülmüştür. Cinsiyet, anne ve baba mesleği veya eğitim düzeyleri farklılaşma oluşturmamıştır. 
Yukarıda belirtilen çalışmalar incelendiğinde, yaratıcı dramanın akademik başarı, hatırlama düzeyi, problem çözme becerisi gibi değişkenler üzerindeki etkisinin incelendiği görülmektedir. Araştırmalar genellikle ilköğretim düzeyindedir. Daha çok Sosyal Bilgiler dersi kapsamında araştırmaya konu olan yaratıcı drama yöntemi, coğrafya öğretiminde ortaöğretim düzeyinde oldukça sınırlı sayıda çalışılmıştır. Bu bağlamda lisans düzeyinde olan bu çalışma ayrıca önem arz etmektedir. Öğretmen adaylarının yöntemle ilgili bilgi ve deneyimlerini arttırmak, meslek yaşantılarına etkisi adına oldukça önem arz etmektedir. Bu bağlamda araştırmanın problem cümlesi;

"Coğrafya öğretmeni adaylarının yaratıcı drama yöntemine ilişkin görüşleri nelerdir?” şeklinde belirlenmiştir. Bu problem cümlesine bağlı olarak aşağıdaki alt problem cümlelerine cevap aranmıştır:

1. Coğrafya öğretmeni adaylarının yaratıcı drama eğitim alma durumu nedir?

2. Coğrafya öğretmeni adaylarının yaratıcı drama hakkındaki görüşleri nelerdir?

3. Coğrafya öğretmeni adaylarına göre yaratıcı dramanın coğrafya dersi ve diğer derslere uygulanabilirliği nedir?

4. Coğrafya öğretmeni adaylarının yaratıcı drama uygulamaları ile ilgili önerileri nelerdir?

\section{Yöntem}

$\mathrm{Bu}$ araştırmada öğretmen adaylarının yaratıcı drama yöntemine ilişkin görüşleri incelenerek nitel yaklaşıma dayalı bir çalışma yapılmıştır. Uygulama 2014-2015 güz yarı yılında KTÜ Fatih Eğitim Fakültesi Coğrafya Öğretmenliği programına devam eden öğretmen adayları ile gerçekleştirilmiştir. $\mathrm{Bu}$ öğretmen adayları 4. ve 5. sınıf coğrafya öğretmen adayları $(n=30)$, ve coğrafya öğretmenliği pedagojik formasyon öğrencilerinden $(n=43)$ oluşmaktadır. Araştırma grubuna yaratıcı dramaya dayalı bir ders planı sunulmuştur (Ek 1). Araştırmacılar tarafindan geliştirilen bu ders planı ile ilgili olarak coğrafya eğitimi alanında uzman bir öğretim üyesi ve drama uygulamaları içeriğindeki dersleri yürüten bir öğretim elemanının görüşü alınmıştır. Dönütlere bağlı olarak gerekli düzenlemeler yapıldıktan sonra bu plan “Özel Öğretim Yöntemleri” dersi kapsamında öğretmen adaylarına uygulanmış ve uygulama sonunda yarı yapılandırılmış form dağıtılmıştır. Uygulama 1 ders saati sürmüştür. Formlar 2 gün sonra toplanarak ev ortamında rahat bir şekilde ve birbirlerinden etkilenmeden doldurulması sağlanmıştır. Bu form 12 sorudan oluşmaktadır. Soruların kapsam geçerliği alan uzmanı olan iki öğretim elemanı tarafından sağlanmıştır. Formların analizi ile elde edilen bulgulara içerik analizi uygulanmıştır. Araştırmanın güvenirliğini sağlamak için her üç araştırmacı tarafından bağımsız şekilde kodlama yapılarak sonuçlar karşılaştırılmış, birbiri ile uyumlu kodlamaların yapıldığı görülmüştür. Bu şekilde, kodlamaların ön yargı ve yanlış anlamadan uzak, ortak bir bakış açısına göre yapılması sağlanmıştır. Kodlar arasındaki ilişkilerin ana hatları belirlenerek temalar oluşturulabilmesi için araştırmacıların fikir birliğine varması gözetilmiştir. Bulguların anlaşılabilirliğini arttırmak için ortaya çıkan kod ve temalar tablolaştırılmış, NVivo 10 programı ile modellenmiş ve örnek cümlelerle desteklenmiştir. 


\section{Bulgular}

Araştırmanın bu bölümünde alt problem cümleleri ile bağlantılı olarak, bulgular sunulmuştur. Araştırmanın ilk alt problem cümlesi, "Coğrafya öğretmeni adaylarının yaratıcı drama eğitimi alma durumu nedir?" şeklindedir. Bu alt problem ile ilgili bulgular aşağıda tablo 1'de gösterilmiştir.

Tablo 1. Coğrafya öğretmeni adaylarının yaratıcı drama ĕgitimi alma durumları

Coğrafya öğretmeni adaylarının yaratıcı drama eğitimi alma durumları

\begin{tabular}{|c|c|c|c|}
\hline \multirow{2}{*}{ Eğitimim yok } & İstiyorum & $\begin{array}{c}2,3,13,14,15,18,19,23,27,28,32,34,35,36,38 \\
40,41,42,43,45,46,47,48,49,50,52,53,54,57 \\
59,60,65,67,68,69,71\end{array}$ & 36 \\
\hline & İstemiyorum & $\begin{array}{c}5,6,7,11,12,16,17,22,24,25,26,31,33,37,39 \\
44,51,55,56,58,61,66,70,72,73\end{array}$ & 25 \\
\hline Eğitimim var & (En fazla 1 ay) & $8,20,29,46,63$ & 5 \\
\hline $\begin{array}{l}\text { Tablo } \\
\text { incelendiğinde, } \\
\text { yönelik eğitim a } \\
\text { kişi iken, almay } \\
\text { istemektedir. Ge } \\
\text { Ö69 "Hayır ame }\end{array}$ & $\begin{array}{l}\text { 'de coğrafya ö } \\
\text { raştırma grubunı } \\
\text { anların almayanl } \\
\text { In } 61 \text { kişi bulunm } \\
\text { riye kalan } 25 \text { kişi } \\
\text { KPSS'den kurtu }\end{array}$ & $\begin{array}{l}\text { ğretmen adaylarının yaratıcı drama eğitim alma } \\
\text { oluşturan öğretmen adayları içerisinde yaratıcı drama y } \\
\text { ara göre oldukça az olduğu görülmüştür. Bu eğitimi ala1 } \\
\text { aktadır. Bu eğitimi almayanların } 36 \text { kişisi bu alanda eği } \\
\text { ise bu eğitimi almayı düşünmemektedir. Öğretmen ada } \\
\text { unca almayı düşünüyorum." }\end{array}$ & adec \\
\hline
\end{tabular}

Araştırmanın ikinci alt problem cümlesi, "Coğrafya öğretmeni adaylarının yaratıcı drama hakkındaki görüşleri nelerdir?” şeklindedir. Bu alt problem ile ilgili bulgular tablo 2' de gösterilmiştir. 
Tablo 2. Coğrafya ögretmeni adaylarının yaratıcı drama hakkındaki görüşleri

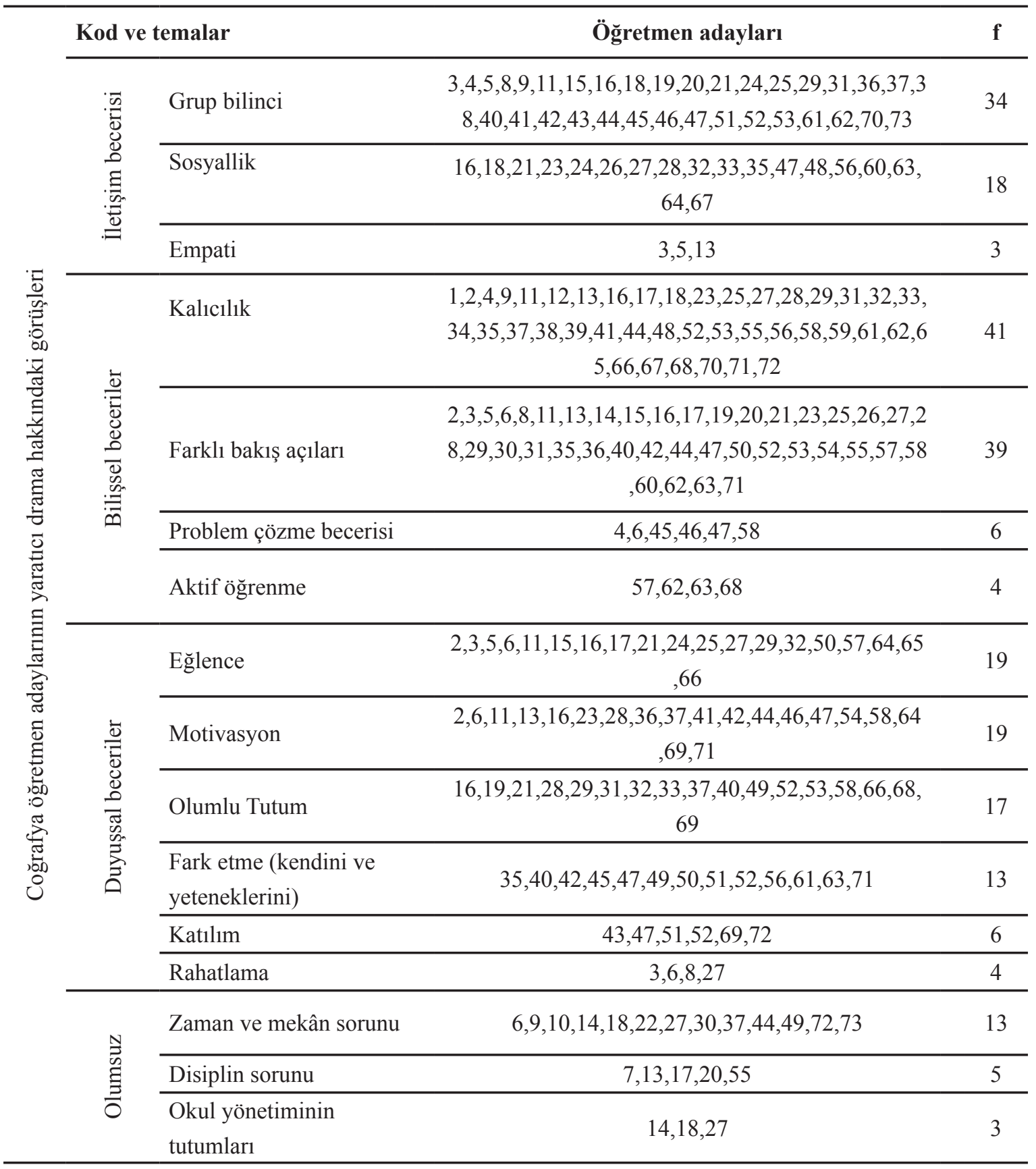

Tablo 2'de coğrafya öğretmen adaylarının yaratıcı drama hakkındaki görüşleri incelendiğinde olumlu ve olumsuz olmak üzere iki tema altında bulguların sınıflandırılabileceği görülmektedir. Öğretmen adaylarının yarıdan fazlası yaratıcı drama yöntemine yönelik olumlu görüş ifade etmiştir. Olumlu görüş bildirenler iletişim becerisinde, bilişsel becerilerde ve duyuşsal becerilerde gelişim sağlayabileceği yönünde temalar oluşturacak cevaplar vermişlerdir. Olumlu görüş ifade edenlerden, iletişim becerisini geliştirir diyenler çoğunluktadır $(\mathrm{f}=55)$.l̇letişim becerisi dahilinde grup bilinci ( $\mathrm{f}=34)$, sosyallik $(\mathrm{f}=18)$ ve empati $(\mathrm{f}=3)$ kodları oluşturulmuştur. Bilişsel beceriler oluşturan temada, kalıcılık sağlayacağı $(\mathrm{f}=41)$, farklı bakış açılarını geliştireceği $(\mathrm{f}=39)$, problem çözme becerisini 
arttıracağı (f=6), aktif öğrenme sağlayacağına dair ( $\mathrm{f}=6)$ kodlar bulunmaktadır. Duyuşsal becerileri geliştireceğine dair tema ise; eğlendirmesi ( $\mathrm{f}=19)$, motivasyonu arttırması ( $\mathrm{f}=19)$, derse yönelik olumlu tutum geliştirmesi ( $\mathrm{f}=17$ ), kendine ve yeteneklerine yönelik farkındalık sağlaması ( $\mathrm{f}=13$ )'na ilişkin kodlardan oluşmuştur.

Coğrafya öğretmen adayları içinde yaratıcı drama için zaman ve mekânın yetmeyeceği (f=13) görüşünde olanlar da mevcuttur. Ayrıca yöntemin disiplin sorunu doğurabileceği ( $f=5)$ ve bu sebeple okul yönetiminin yöntemi olumsuz karş1layabileceği ( $\mathrm{f}=3$ ) düşüncesinde olanlar da mevcuttur.

Öğretmen adayı ifadelerine örnek olarak; Ö 44 "Grup bilincini arttırır ve sinerjiyi ortaya çıkarır. Öğrenciler arasındaki ilişkiler, bağlar artar”, Ö 18 “Öğrenmeyi eğlenceli ve öğrencinin aktif olarak katıldığı bir etkinlik haline getiriyor. Ö 50 "Yaratıcı drama eğitimi alan birey, kendi sınırlarını daha iyi görebilir." gösterilebilir.

Araştırmanın üçüncü alt problem cümlesi, "Coğrafya öğretmen adaylarına göre yaratıc1 dramanın coğrafya dersi ve diğer derslere uygulanabilirliği nedir?” şeklindedir. Bu alt problem ile ilgili bulgular şu şekildedir:

Tablo 3. Coğrafya öğretmen adaylarının yaratıcı dramanın coğrafya dersi ve diğer derslere uygulanabilirliği hakkındaki görüşleri

\begin{tabular}{|c|c|c|c|}
\hline \multicolumn{2}{|c|}{ Kod ve temalar } & \multirow{2}{*}{$\begin{array}{c}\text { Öğretmen adayları } \\
1,4,10,11,14,17,18,24,25,27,30,33,34,37,40,44,45,46, \\
47,48,49,50,53,57,58,59,65,68,70,72,73\end{array}$} & \multirow{2}{*}{$\mathbf{f}$} \\
\hline 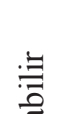 & Beşeri coğrafya & & \\
\hline$\frac{\mathrm{E}}{\Xi}$ & Fiziki coğrafya & $1,2,10,15,16,23,26,28,30,31,36,60,65,72,73$ & 15 \\
\hline$\stackrel{b}{S}_{S}^{\infty}$ & Tüm konularda & $35,41,42,52,54,55,63,64,66$ & 9 \\
\hline \multirow{3}{*}{ 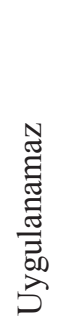 } & Fiziki coğrafya & $\begin{array}{c}1,5,10,13,14,15,17,18,19,20,21,24,25,26,27,28,29,30 \\
32,36,45,48,49,50,57,59,72\end{array}$ & 26 \\
\hline & Sayisal dersler & $\begin{array}{c}14,16,17,19,20,21,28,29,30,36,38,40,44,45,47,56,57 \\
60,65,72\end{array}$ & 20 \\
\hline & Sözel dersler & $1,2,4,5,10,13$ & 6 \\
\hline
\end{tabular}

Tablo 3'deyaratıcı dramanın coğrafya dersi ve diğer derslere uygulanabilirliği hakkındaki görüşler incelenmiştir. Coğrafya öğretmen adayları çoğunlukla yaratıcı drama yönteminin coğrafya ve diğer derslere uygulanabilir olduğunu düşünmektedir. Araştırma grubu içerisinde yöntemin en kolay beşeri coğrafya konularında uygulanabileceği ifade edilmiştir (f=31). Öğretmen adaylarının bir kısmı da fiziki coğrafya konularında yaratıcı dramanın uygulana bileceğini belirtmişlerdir(f=15). Ayrıca öğretmen adaylarından tüm konularda uygulanabileceği cevabı da gelmiştir(f=9). Öğretmen adaylarından, yaratıcı dramanın kullanılamayacağını ifade edenler de mevcuttur. Fiziki coğrafya konularında kullanılmaz olarak ifade edenler $(\mathrm{f}=26)$, sayısal derslerde kullanılamaz olarak ifade edenler ( $\mathrm{f}=20)$ ve sözel derslerde kullanılamaz olarak ifade edenler $(\mathrm{f}=6)$ bulunmaktadır.

Yaratıcı dramanın coğrafya dersine uygulanabilirliği hakkında görüşler: Ö48 "Beşeri coğrafya konularına uygulanabilir. Daha çok insan ve doğa etkileşimi konuları veya çevre toplum konularında başarılı olabilir”, Ö64 “Kesinlikle uygulanabilir diye düşünüyorum. Coğrafya birçok yeteneği içinde 


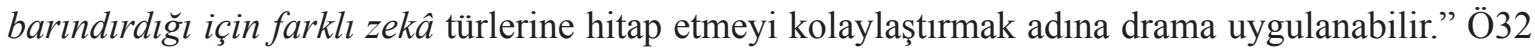
"Her derste illa ki bir konu hakkında drama yapılabilir diye düşünüyorum."

Araştırmanın dördüncü alt problem cümlesi, "Coğrafya öğretmen adaylarının yaratıcı drama uygulamaları ile ilgili önerileri nelerdir?” şeklindedir. Bu alt problem ile ilgili bulgular aşağıda tablo şeklinde gösterilmiştir.

Tablo 4. Coğrafya ögretmen adaylarının yaratıcı drama uygulamaları ile ilgili önerileri

\begin{tabular}{ccc}
\hline Kod ve temalar & Öğretmen adayları & $\mathbf{f}$ \\
\hline Planlamalar yapılmalı & $15,21,23,27,32,33,40,41,49,53,61$ & 11 \\
\hline Uygun koşullar sağlanmalı & $1,4,17,39,41,53,64,65,67$ & 9 \\
\hline Ders saatleri artırılmalı & $10,15,17,23,31,49,51,68$ & 8 \\
\hline Yaratıcı drama yaygınlaştırılmalı & $14,25,32,37,40,70$ & 6 \\
\hline Ücretsiz olmalı & $21,24,26,27,28$ & 5 \\
\hline
\end{tabular}

Tablo 4'deki coğrafya öğretmeni adaylarının yaratıcı drama uygulamaları ile ilgili önerileri incelendiğinde öğretmen adayları en çok yaratıcı dramanın planlaması konusunda öneride bulunmuştur ( $f=11)$. Ayrıca öğretmen adayları uygun koşulların sağlanması $(f=9)$, ders saatlerinin artırılması ( $\mathrm{f}=8)$, yaratıcı dramanın tanıtılması ve yaygınlaştırılması $(\mathrm{f}=6)$ ve ücretsiz hale getirilmesi $(\mathrm{f}=5)$ gerektiği belirtilmiştir. Ö 49'un yaratıcı drama hakkındaki önerisi: “Tanıtmak gerekir. Bizler bunu 24 yaşında öğrendik, bence ilköğretimden itibaren yılda birkaç kez kullanılmalı-Ağaç yaş iken eğilir-.

\section{Sonuç ve Tartışma}

Yapılan araştırmada bulgulara dayanarak elde edilen sonuçlar NVivo 10 ile modellenerek aşağıda sunulmuştur.

Model 1. Coğrafya öğretmen adaylarının yaratıcı drama yöntemine ilişkin görüşlerine dair model

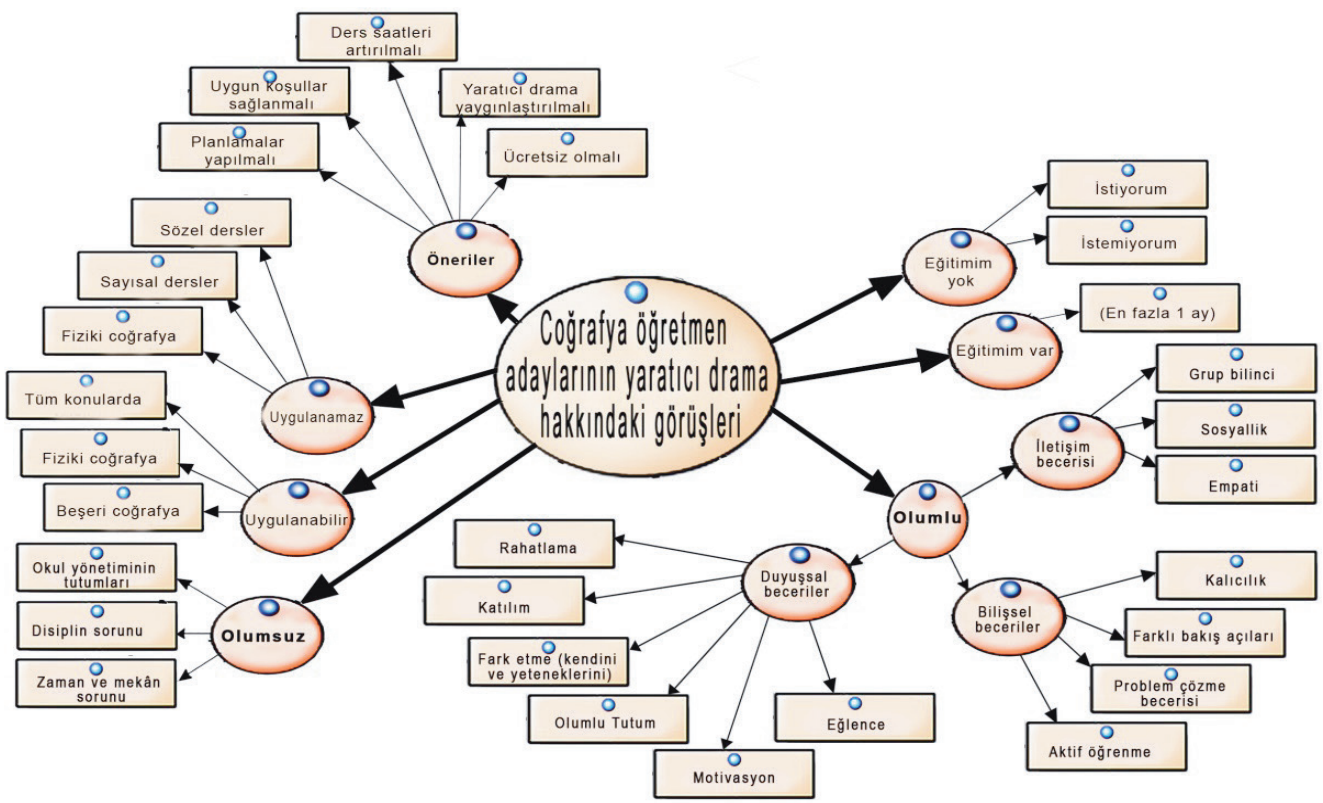


Model 1'de görüldüğü gibi coğrafya öğretmen adaylarının yaratıcı drama eğitimi alma durumları oldukça azdır. Buna karşın bu eğitimi almak istemektedirler. Katılımcıların çoğunluğu yaratıcı drama yöntemine yönelik olumlu görüş ifade etmişlerdir. Yapılan diğer çalışmalarda da yönteme yönelik olumlu özelliklerin vurgulandığı sonuçlara ulaşılmıştır (Koç, 1999; Özcan, 2004; Esen, 2008; Hamurcu, 2009; Akkaya, 2012). Araştırmada olumlu görüş ifade edenlerin büyük çoğunluğu, yaratıcı dramanın iletişim becerileri ile bilişsel ve duyuşsal becerileri geliştirdiği fikrine sahiptir. Araştırma sonucuna göre; yaratıcı drama, coğrafya derslerinde grup bilincini arttırıp sosyalleşmeye katkı sağlamaktadır. Empati yeteneğini geliştirmektedir. Ayrıca bilişsel alanda kalıcılık sağlayıp, problem çözme becerisini arttırmaktadır. Öğrencileri aktif öğrenmeye yöneltmektedir. Duyuşsal olarak eğlenme duygusu ve motivasyon ile olumlu tutum geliştirmektedir. Yenilmez ve Uygan (2010)'ın belirttiği gibi, çağdaş öğretim yöntemlerinden birisi olan yaratıcı drama yöntemi, öğrencilere derslerde aktif rol oynama firsatı vererek hem kendi yeteneklerinin farkına varmalarını hem de soyut kavramları kendi hayal dünyalarında somutlaştırarak öğrenmelerini sağlamaktadır. Tekin (2007, s. 125), dramanın öğrencilerin motivasyonunda önemli katkılar sağladığını belirtmiştir. Birey, kendine ve yeteneklerine yönelik farkındalık sağlamaktadır. Kalıcılık, motivasyon, kendini tanıma, problem çözme gibi bulgular açısından Timuçin'in (2011, s. 57) “Öğretmen adayları drama ile öğrencilerin eğlenerek ve oynayarak kalıcı olduğunu düşünmektedir.” ifadesi örtüşmektedir.

Özel mekânlara gereksinim duyması ve zaman gerektirmesi, yöntemin sınırlılıkları arasında gösterilmiştir. Ayrıca disiplin sorununa yol açması ve okul yönetiminin olumsuz tutum sergilemesi de yönteme gelen eleştiriler arasındadır. Coğrafya öğretmen adaylarınca yaratıcı drama yöntemi, coğrafya derslerinin konularına ve diğer disiplinlere uyarlanabilir bulunmuştur. Yöntemin diğer konu ve derslerde uygulanabilirliği ile ilgili Esen (2008)'in çalışması da benzer sonuçlar içermektedir. Coğrafya dersinin en çok beşeri coğrafya konularına uygulanabileceği düşünülmektedir. Yöntemi sınırlı görenler, özellikle fiziki coğrafya konularının öğretimi için uygun bulmamışlardır. Bunun yanında, sayısal derslerde (fizik, kimya, biyoloji, matematik vs.) uygulanması sözel derslere göre daha güç bulunmuştur. Yöntemin kullanımının kısıtlı konu ve disiplinlere uygun görülmesi, Özcan (2004)'e ait çalışmanın bulguları ile örtüşmektedir. Sözel derslerde yaratıcı drama yöntemine ilişkin yapılan çalışmalar incelendiğinde (Akkaya, 2012; Koç, 1999; Esen, 2008; İşleyen, 2009) yaratıcı dramanın sözel derslerde yöntem olarak uygulanabildiği görülmüştür. Ayrıca, benzer durum sayısal derslerde de geçerlidir. Örneğin matematik alanında yapılan çalışmada Yıldız (2011), matematik öğretiminde yaratıcı drama yönteminin uygulanabilir olduğunu belirtmiştir. Taş (2008)'ın, yine matematik öğretimi alanında yaptığı çalışmasında, değişik problem çözüm yollarının yorumlanmasının anlamaya katkı sağladığı tespit edilmiştir. Fen Bilgisi öğretiminde drama yöntemini kullanan Cihan (2006)'a göre, Fen Bilgisi eğitimde yaratıcı drama, geleneksel yöntemlere göre daha etkilidir. Coğrafya öğretmen adaylarının bu konudaki ön yargılarının, drama bilgi ve yaşantılarının yetersiz olmasından kaynaklandığı düşünülmektedir. Coğrafya öğretmen adayları, yaratıcı drama uygulamasından önce detaylı bir plan yapılmasını önermişlerdir. Ayrıca mekân ve zaman açısından uygun alt yapının sağlanması ve ders saatlerinin artırılması önerilerini getirmişlerdir. Coğrafya öğretmen adaylarının yaratıcı drama yöntemine ilişkin bir diğer önerileri ise yöntemin tanıtımının yapılarak yaygınlaştırılması ve ücretsiz hale getirilmesidir. Akkaya (2012) yapmış olduğu çalışmada, sınıf ortamlarının yaratıcı drama yöntemini kullanmaya pek müsait olmaması, uygulama süresinin kısa olması ve öğretmenlerin yaratıcı drama konusunda eğitilmesi gerekliliğinden bahsetmektedir. Bu bulgular araştırmanın bulguları ile örtüşmektedir. Benzer şekilde Erdoğan (2011) da çalışmasında 
zaman, hazırbulunuşluk düzeyleri ve fiziksel şartlardaki olumsuzluklar gibi sorunları dile getirmiştir. Benzer şekilde Ormancı ve Şaşmaz (2010) tarafından yapılan çalışma da yaratıcı dramanın uygulanmasıyla ilgili öğretmen ve öğrenci özellikleri, araç-gereç yetersizliği, yönetim, sınıfın fiziki imkânları, zaman ve sınıf gibi engeller saptamıştır.

\section{Öneriler}

Çalışma sonunda çıkarılan sonuçlardan hareketle şu önerilerde bulunulabilir:

1. Hazırlanan ders planı ortaöğretim öğrencilerine uygulanabilir.

2. Hazırlanan ders planı ile ilgili öğretmen, öğrenci görüşleri de alınarak karşılaştırmalı bir çalışma yapılabilir.

3. Yaratıcı drama yöntemi coğrafya derslerinde yaygın şekilde kullanılabilir. Bunun için hizmet öncesi ve içinde eğitimler verilmelidir.

4. Yaratıcı dramayı uygulayan eğitmen/lider tecrübe sahibi olmalıdır. Sınıfa en etkili şekilde hakim olmalıdır ki uygulama sırasında aksayan yönleri düzeltebilsin.

5. Yaratıcı drama uygulamasının daha uzun süreli gerçekleştirilerek yaratıcılığa, problem çözme becerisine, tutum ve psikomotor becerilerin gelişimine etkisi araştırılabilir.

6. Yaratıcı dramanın hem öğretmenlere hem öğretmen adaylarına tanıtımının yapılması önerilmektedir. Böylelikle karşılaşılan birçok sorun giderilebilir.

7. Yaratıcı drama oturumunu uygulamadan önce (drama eğitimleri yoksa), tanışma, iletişim ve etkileşim gerçekleştirebilecek bir oturumun hazırlanıp uygulanması önerilmektedir.

\section{Kaynakça}

Adıgüzel, Ö. (2013). Eğitimde yaratıcı drama (3. bs). Ankara: PegemA Yayınc1lık.

Akkaya, M. (2012). Sosyal bilgilerde göç konusunun drama yöntemiyle öğretiminin akademik başarıya etkisi. Yayımlanmamış yüksek lisans tezi, Gazi Üniversitesi Eğitim Bilimleri Enstitüsü, Ankara.

Atar, G. (2003). Ĕgitici dramanın sosyal bilgiler dersi coğrafya konularının öğretiminde kullanmanın öğrenmenin kalıcllı̆̆ üzerindeki etkileri. Yayımlanmamış yüksek lisans tezi, Marmara Üniversitesi Eğitim Bilimleri Enstitüsü, İstanbul.

Cihan, Y. G. (2006). Fen bilgisi ögretimde drama yönteminin kullanımı. Yayımlanmamış yüksek lisans tezi, Pamukkale Üniversitesi Fen Bilimleri Enstitüsü, Denizli.

Çelikkaya, T. (2014). Sosyal bilgiler dersinde drama yönteminin önemi ve uygulama örnekleri. Turkish Studies-International Periodical For The Languages, Literature and History of TurkishorTurkic, 9(2), 447470.

Debre, İ. (2008). İlköğretim sosyal bilgiler dersi coğrafya konularının öğretiminde ders anlatım stratejisi olarak dramatizasyonun kullanılmasının ögrencinin başarı düzeyine etkisi. Yayımlanmamış yüksek lisans tezi, Yeditepe Üniversitesi Sosyal Bilimler Enstitüsü, İstanbul.

Erdoğan, T. (2011). Sınıf öğretmenlerinin Türkçe derslerinde yaratıcı drama yöntemini kullanma durumlarının incelenmesi. Çağdaş Drama Derneği Yaratıcı Drama Dergisi, 12 (6), 23-36.

Esen, M. (2008). IX. sinıf coğrafya dersi konularının (yerkürenin günlük hareketi, iklim bilgisi, toprak coğrafyası, jeolojik zamanlar) ögretiminde drama yöntemi ile klasik yöntemlerin karşılaştırllması. Yayımlanmamış yüksek lisans tezi, Gazi Üniversitesi Eğitim Bilimleri Enstitüsü, Ankara. 
Hamurcu, H. (2009). Sınıf öğretmenliği bölümü öğrencilerinin yaratıcı dramaya yönelik tutumları. E-Journal of New World Sciences Academy, 4(4), 1243-1256.

İşleyen, E. (2009). Ortaöğretim dokuzuncu sinıf Türk edebiyatı dersinde drama yönteminin öğrencilerin ders başarısına katkısı (Ankara ili-Akyurt ilçesi örneği). Yayımlanmamış yüksek lisans tezi, Gazi Üniversitesi Eğitim Bilimleri Enstitüsü, Ankara.

Koç, F. (1999). Yaratıcı dramanın öğrenmeye etkisi -Sosyal bilgiler öğretiminde bir yöntem olarak-. Yayımlanmamış yüksek lisans tezi, Ankara Üniversitesi Sosyal Bilimler Enstitüsü, Ankara.

Koç, İ. (2013). Öğretmenlerin sosyal bilgiler dersinde drama yöntemini uygulama ve drama tekniklerine ilişkin yeterliliklerinin belirlenmesi. Yayımlanmamış yüksek lisans tezi, Ahi Evran Üniversitesi Sosyal Bilimler Enstitüsü, Kırşehir.

Köseoğlu, İ. ve Ünlü M. (2006). Coğrafya dersinde drama tekniğinin öğrenci başarına etkisi. Marmara Coğrafya Dergisi, 13, 125-132.

MEB. (2006). Mesleki eğitim ve öğretim sisteminin güçlendirilmesi projesi (MEGEP). Çocuk Gelişmi ve Eğitimi Drama Çalışmaları. Ankara: Milli Eğitim Bakanlığı.

hbogm.meb.gov.tr/modulerprogramlar/.../dramacalismalari.pdf (Erişim tarihi 18.03.2015)

MEB. (2011). Coğrafya dersi öğretim progamı (9, 10, 11 ve 12. sınıflar)(Değişiklik). [Elektronik Sürüm]. Ankara: Milli Eğitim Bakanlı̆̆ı.

Ormancı, Ü. ve Şaşmaz, Ö. F. (2010). Dramanın ilköğretimde kullanılabilirliğine yönelik sınıf öğretmeni adaylarının görüşleri: Demirci Eğitim Fakültesi örneği. Ankara Üniversitesi Eğitim Bilimleri Fakültesi Dergisi, 1(43), 165-191.

http://dergiler.ankara.edu.tr/detail.php?id=40\&sayi_id=1342 (Erişim tarihi 24.03.2015)

Özcan, H. (2004). İlköğretim 5. sınıf sosyal bilgiler dersi coğrafya konularının ögrretimde drama yönteminin kullanılması (Kazan ilçesi örneği). Yayımlanmamış yüksek lisans tezi, Gazi Üniversitesi Eğitim Bilimleri Enstitüsü, Ankara.

Rüzgâr, A. M. (2014). 6.sınıf sosyal bilgiler programındaki ipek yolunda Türkler ünitesinde geçen göç kavramının drama yöntemiyle işlenmesinin öğrenci başarısına etkisi. Yayımlanmamış yüksek lisans tezi, Giresun Üniversitesi Sosyal Bilimler Enstitüsü, Giresun.

San, İ. (1990). Eğitimde yaratıcı drama, Ankara Üniversitesi Eğitim Bilimleri Fakültesi Dergisi, 23(2), 573 582. http://dergiler.ankara.edu.tr/detail.php?id= 40\&sayiid $=508$ (Erişim tarihi 21.03.2015)

San, İ. (2010). Türkiye'de eğitimde yaratıcı drama çalışmaların gelişimi. Ömer Adıgüzel (Ed.) Yaratıcı Drama 1999-2002 Yazılar, s.18-29. Ankara: Naturel Yayıncılık.

Taş, F. (2008). İlköğretim 1.-5. sınıflar matematik dersi temel becerilerine drama tekniğinin katkısına ilişkin öğretmen görüşleri. Yayımlanmamış yüksek lisans tezi, Abant İzzet Baysal Üniversitesi Sosyal Bilimler Enstitüsü, Bolu.

Tekin, S. (2007). Hizmet-içi eğitimin öğretmenlerin drama hakkındaki görüşlerine etkisi. N. Aslan (Ed). Türkiye 9. Drama Liderleri Buluşması ve Ulusal Drama Semineri içinde (s.63-75). Drama kavramları. Ankara: Oluşum Yayınları.

Turan, İ., Kuğuoğlu, H. İ. ve Albayrak, O. (2012). Öğretmen adaylarının drama öz yeterliliği ve coğrafya, tarih ve vatandaşlık bilgileri konularında drama kullanımı. NWSA-Education Sciences, 3 (7), 1004-1016.

Timuçin, E. (2011). Bir yaratıcı drama sürecinin ardından öğretmen adaylarının görüşleri. 18-19-20 Nisan 2011 Uluslararası Eğitimde Yaratıcı Drama Sетроzуити (s.53-59). İstanbul: İstanbul Üniversitesi.

Yeğen, G. (2008). Matematik öğretmen adaylarının eğitiminde dramanın sağlayacağı bireysel ve mesleki katkılara yönelik düşünceleri. N. Aslan (Ed). Türkiye 10. Drama Liderleri Buluşması ve Ulusal Drama Semineri (s.17-23). Ankara: Eğitimde Drama Oluşum Yayınları.

Yenilmez, K. ve Uygan, C. (2010). Yaratıcı drama yönteminin ilköğretim 7. sınıf öğrencilerinin geometriye yönelik özyeterlik inançlarına etkisi. Kastamonu Eğitim Dergisi, 3 (18), 931-942. 
Yıldız, E. (2011). Yaratıcı dramayı matematik öğretimde yöntem olarak kullanan öğretmenlerin ve öğretim elemanlarının yönteme ilişkin görüşlerinin değerlendirilmesi. Yayımlanmamış yüksek lisans tezi, Ankara Üniversitesi Eğitim Bilimleri Enstitüsü, Ankara.

Zayimoğlu, F. (2006). İlköğretim 6. sınıf sosyal bilgiler dersi “coğrafya ve dünyamız” ünitesinde yaratıcı drama yöntemi kullanımının öğrenci başarısı ve tutumlarına etkisi. Yayımlanmamış yüksek lisans tezi, Gazi Üniversitesi Eğitim Bilimleri Enstitüsü, Ankara.

\section{Ek: 1}

“C.10.18. Türkiye’deki göçlerin sebep ve sonuçlarını coğrafi açıdan sorgular.” Coğrafya kazanımına göre hazırlanmış Yaratıcı drama oturumu

Ders: Coğrafya

Lider: Mehmet Akif Bütün

Konu: Türkiye'de Göçler

Kazanım: C.10.18. Türkiye'deki göçlerin sebep ve sonuçlarını coğrafi açıdan sorgular.

Süre: 60 dakika

Sınıf (Çalışılacak Grup): 30 kişi

Araç- Gereçler: Kalem, Fon kartonu

Yöntem ve Teknikler: Yaratıcı drama, rol oynama, doğaçlama, istasyon tekniği

\section{SÜREC}

\section{A. Isinma}

1. Etkinlik: Çember olunur. Çemberde lider katılımcılara birtakım yönergeler verir. Lider verdiği yönergeler ile çemberde bulunan katılımcılar yer değiştirir. Yönergeler şöyledir:

1. Daha önce göç eden bir aile ya da göç eden bir kişi görenler yer değiştirsin.

2. Daha önce sağlık nedeni ile bir yerden başka bir yere göç edenler yer değiştirsin.

3. Daha önce eğitim nedeni ile bir yerden başka bir yere göç edenler yer değiştirsin.

4. Daha önce ekonomik nedenlerden dolayı bir yerden başka bir yere göç edenler yer değiştirsin. (Bu yönergeler Songül Başbuğ hocanın 3. aşama yaratıcı drama atölyesinden esinlenerek konuya uyarlanmıştır.)

\section{Etkinlik}

Lider katılımcılara alanda serbest bir halde yürümelerini söyler. Katılımcılar alanda serbest halde yürürken, lider katılımcılara verdiği yönerge/kavramlara ilişkin donuk imge oluşturmalarını söyler. Yönergeler;

1. Yeni evlendiniz ve çok mutlusunuz.

2. Yolculuk yapan bir kişiniz.

3. Savaş mağduru bir kişisiniz.

4. Kan davasından kaçan bir kişisiniz.

5. Depremde anne ve babanızı kaybetmiş bir kişisiniz.

6. Okuldan mezun oldunuz ve yeni bir şehre atandınız.

\section{Etkinlik (Ev sahibi-Kiracı Oyunu)}

Lider katılımcılara 3 kişilik gruplar oluşturmalarını söyler. Her grupta katılımcılardan iki kişi el ele tutuşurlar ve bir çember oluştururlar. Gruptaki üçüncü kişi ise çemberin ortasında durur. Lider ya da 3 kişilik grup oluşturamayan katılımcılar ebe olur. Ebe "Göç” dediğinde çemberin ortasındakiler çıkarlar ve başka çemberlere yer değiştirerek göç ederler. İnsanlar göç ederken çemberin ortasında yeri olmayan ebeler de göç edecekleri çemberlere doğru giderler. Ebe "Beyin göçü” dediğinde bu sefer herkes yer değiştirmeye başlar ve ebe de kendisine ya ev sahibi ya da ev bulmaya çalışır. 


\section{Etkinlik}

Lider, katılımcılara mekânın herhangi bir köşesine doğru gitmelerini ve bir arada durmalarını söyler. Yönergeler geldikçe küçük adımlarla ilerlenir ve her yönerge söylendikten sonra donuk imge ile lider tarafından söylenen sözcükleri canlandırılır.

Yolculuk... kalabalık... öksürük nöbetleri... devlet bursu... deprem... silah sesleri... savaş... evlilik... memuriyet... diploma töreni... korku... terör... sarsıntı... heyecan....panik... ölüm... yaralı... ambülans... tarlada mahsul toplama... okumak istiyorum...bavul... ayrılık... hüzün...

\section{B. Canlandirma}

\section{Durum}

A ve B anne-babadır. Bu A ve B kişileri köyde yaşamaktadır. Geçimlerini tarım ve hayvancılıkla sağlamaktadır. Çocuklarını köyde bulunan bir ilköğretimde okutmuşlardır. Ancak, çocukları büyümüş lise çağına gelmiştir. A (anne), çocuklarını daha iyi eğitim alsınlar diye şehirde okutmak istemektedir ve bu nedenle şehre göç etmek istemektedir. B (baba) ise çocuklarını okutmak istemeyip baba mesleği olan tarım ve hayvancılıkla uğraşmalarını istemektedir. A'nın (anne) çocuklarını şehirde okutmak istemesinin gerekçesi, tarım ve hayvancılıktan eskisi kadar verim almamaları olarak açıklamaktadır. B'nin (baba) çocuklarını okutmak istememesinin gerekçesini, bulunduklarını köyün arazi şartlarının elverişsizliği nedeni ile tarım da makine kullanamamak olarak açıklamaktadır. Bu nedenle insan gücüne ihtiyaç vardır. Şehre göç ettiklerinde tarlayı sürecek insan gücü yok olacaktır. Akşam yemeğinde tüm aile sofranın başında toplanır. Doğaçlama başlar.

\section{Durum}

A ve B anne-babadır. Deniz kıyısında bir ilçede yaşamaktadırlar. Geçimleri tarımdan sağlamaktadırlar. Fakat B (baba) astım hastasıdır. B'ye denizin nemli havası ona zarar vermektedir ve sürekli kontrol altında bulunmak zorundadır. A ise yaşadıkları bu ilçeyi bırakıp gitmek istememektedir. Çünkü bu ilçede doğup büyümüştür. A ve B çocukları ile birlikte akşam çay içerlerken, B'nin konuşması ile doğaçlama başlar.

\section{Durum}

A ve B iki kardeştir. Van'da yaşamaktadırlar. Geçen yıl meydana gelen deprem neticesinde anne ve babalarını kaybetmişlerdir ve yaşadıkları ev yıkılmıştır. Yaşamlarını devletin yaptırdığı prefabrik evde sürdürmektedirler. A, yaşadıkları şehirden göç edip amcalarının yaşadığı Konya'ya gitmek istemektedir. Gerekçesi Konya'nın öncelikli deprem kuşağında olmamasıdır. B ise doğup büyüdüğü il olan Van'ı bırakmak istememektedir. A ve B bir gün park da otururlarken A söze başlar.

\section{Değerlendirme}

Lider, katılımcıların sırayla 1, 2, 3, 4, şeklinde saymalarını ve aynı rakamı söyleyenlerin bir araya gelmelerini söyler. Gruplara kâğıt ve kalem dağıtılır. Katılımcılardan yönergelere uygun olarak Türkiye'deki göçleri değerlendirmeleri istenir.

Grup: Göç ile ilgili resim yapma

Grup: Bilinen bir şarkı üzerine göçle ilgili sözler yazarak rap yapma

Grup: Şiir yazma

Grup: Beyin göçünü engellemeye yönelik slogan oluşturma 